Peter Gallo,

Ph.D., University of Presov, Slovakia

Beata Balogova,

Professor, University of Presov, Slovakia

Luba Tomcikova,

Ph.D., University of Presov, Slovakia

Jozef Nemec,

Ph.D., University of Presov, Slovakia

\title{
THE IMPACT OF THE INNOVATIVE TOTAL QUALITY MANAGEMENT TOOL IN SMALL AND MEDIUM-SIZED ENTERPRISES
}

\begin{abstract}
The present paper falling into the field of innovative management tools explores using the Total Quality Management (TQM) tool in the SME sector in Slovakia, attempting to identify barriers to the use of this tool in the given segment. TQM can be ranked among the innovative management tools that are under investigation and in our contribution, we want to bring a new overview of the use of this tool. Our research was based on foreign research in which the TQM management tool is at the forefront of use. On the other hand, we know from the research conducted so far on management tools in our business environment that the use of innovative tools is relatively low. The present research is based on the formulated hypotheses verified using statistical methods, namely the chi-square test of independence. In this research, we worked with hypotheses arguing that there are statistically significant relationships between the lack of personnel and financial resources on the one hand and the use of the innovative TQM management tool on the other hand. These relationships were statistically proved because in both examined hypotheses the expected value of $p$ was lower than 0.05 . We can, therefore, conclude that the lack of financial resources and the lack of skilled labour are among the important barriers to the use of TQM. In the determination of the third hypothesis, we assumed that managers could not agree on the establishment of TQM. This fact can, therefore, contribute to its relatively low use in our business environment. We also consider the incongruity of managers' ideas as a barrier that may have an impact on the use of TQM, and these dependencies were examined by the Chi-square independence test. In verifying this hypothesis, the $p$-value was calculated to be $p>0.05$ proving that this factor has no effect on the use of TQM and there is no dependency between these variables. In the present paper, we also focus on juxtaposing the present investigation with the research conducted to date in the field of innovative management tools. The present research is aimed at identifying barriers to the use of this management tool in an SME environment and at presenting TQM as a modern innovative instrument to be used by companies to manage and measure their performance. By using TQM, the company can align the financial and non-financial factors together and thus increase its competitiveness and meet the expectations of investors and other stakeholders.

Keywords: Total Quality Management, innovative management tools, small and medium enterprises, performance.
\end{abstract}

Introduction. The current business environment features turbulent and constant changes. The growing openness and integration of the world have led to an increase in the importance of comparing individuals, organizations, countries, and regions (Kiselakova et al., 2019). The up-to-date tendencies in the globalization process require that a country's policy ensure its macroeconomic stability (Bilan et al., 2019). Within the globalization processes, any business advantage can be considered a differential advantage within the competition for winning costumers (Hakobyan et al, 2019; Kosikova et al., 2019). Any business aiming at establishing and maintaining its position on the market and achieving the best possible benefits for its owners, employees, and the business itself, must follow the current trends and changes possibly having a big impact on its business activities. In this context, monitoring of a company's performance comes to the fore. The managers, who have to follow current trends and innovations in the market, play a paramount role in the businesses. The bullet point among the company's strategic assets

Cite as: Gallo, P., Balogova, B., Tomcikova, L. \& Nemec, J. (2019). The Impact of the Innovative Total Quality Management Tool in Small and Medium-Sized Enterprises.

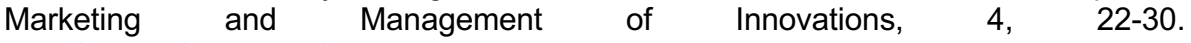
http://doi.org/10.21272/mmi.2019.4-02 

Medium-Sized Enterprises

is effective human resources management which should focus on developing the labour potential (Butko et al., 2019; Onuferova \& Cabinova, 2018). Human capital is a very important factor in technological change, enhancing human potential (Prokopenko et al., 2018; Laguna, 2013; Al Taweel, 2019). Business performance is preconditioned by the managers' ability or potential to achieve the set goals, through their business activities to valorise the invested resources, to generate profits, to increase the value of the company and, at the same time, the ability to ensure its future advancement. Regarding increasing the competitiveness of businesses, it is imperative to pay attention to information technologies that support innovative management tools. The latest trends prove that for a country to achieve economic and IT leadership, it is inevitable to exploit and intensify all types of resources (human, natural, financial, etc.) (Bilan et al., 2019). Modern strategies have to be focused on quality, enterprises should strive to shape an organisational culture that combines these tasks by fitting within the conditions of the knowledge-based economy (Pietruszka-Ortyl, 2019).

In the present paper, we focus on the research of applying the innovative Total Quality Management tool in the small and medium enterprises in Slovakia. It is the use of innovative management tools such as TQM that will support the company in increasing its competitiveness and consequently achieving business appreciation by its owners and shareholders.

Literature Review. There are numerous definitions of TQM. It is generally understood as an integrated management concept and a set of practices that accentuate, among other things, the customers needs satisfaction, continuous improvement, process redesign, competitive benchmarking, team-based problemsolving, closer relationships with suppliers and the constant measurement of achieved results (Ruiz et al., 2019; Bolboli \& Reiche, 2014). Total Quality Management (TQM) is a comprehensive management method that emphasizes quality management in all dimensions of a company's life. It thus exceeds the quality management framework and is understood as a method of strategic management and management philosophy for the entire company. Voluntary participation, feedback loops, rules and goals represent the key elements of total quality management (Beard-Gunter, 2019). There is a variety of forms and interpretations of TQM, however, the common features can be inferred from the initial letters of the acronym:

Total - the total involvement of all the staff of the organization

Quality - the concept of quality principles throughout the organization

Management - principles overlapping at all levels of management including all managerial functions. Applying the TQM concepts is an important issue in reviving a company through building awareness of quality concept throughout all the company's operations (Oluwafemi \& Laseinde, 2020). The TQM principles are applied differently in various organizations and countries, depending on their social, cultural, personal, legislative, technical and other conditions.

TQM pursues wide use of general principles of management, deployment of modern processor service-oriented management, involvement of top managers through leadership (leadership, supporting, in particular, the commitment of all staff, customer orientation and product and service quality, efficient use of organizational resources, eliminating unnecessary costs and pursuing continuous improvement based on clear facts and indicators (Nizamidou et al., 2019; Dahlgaard-Park, 2012). The TQM principles include customer focus, staff engagement, continuous advancement, leadership and clear vision and operations management (Ghani Al-Saffar \& Obeidat, 2020; Chountalas \& Lagodimos, 2019). TQM is a quality-oriented management approach established to engage all organization members and focus on long-term success through customer satisfaction and benefit to all members of the organization and society (Lin et al., 2019; Diaper \& Sanger, 2006). Figure 1 illustrates the TQM principles. 


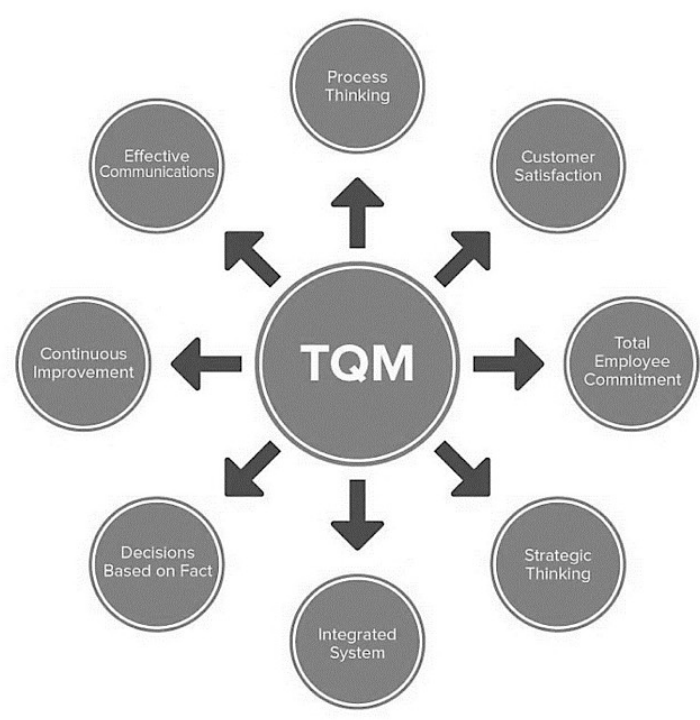

Figure 1. Principles of Total Quality Management

Source: the authors' input based on Feigenbaum (2009).

Strategic decision-making derived from the nature of the operating business sector along with the adoption of TQM practices will revive the company's competitiveness (Sahoo, 2019; Beer, 2003). The success of TQM does not only depend on adopting the TQM attributes, but it is also dependent on complementary factors unrelated to TQM, yet more difficult to adopt than TQM itself. A corporate culture receptive to change, leadership, and motivation for improvement appear to be inevitable (Abdul, 2019; Tenji \& Foley, 2019). The development quality system through applying TQM (Total Quality Management) comprises effective strategy, staff development, the introduction of instructions for product and service quality improvement and enhancing the business processes (Miterva et al., 2019). TQM is an integrated management concept based on a set of social and technical factors that must be put into practice through a reference framework, such as the one contained in the EFQM model (Calvo-Mora, et al. 2014). TQM as an approach offers strategies and tools (such as total involvement of all employees, teamwork, feedback instruments, and extensive communication) that are inherently useful as enablers of knowledge creation and dissemination (Colurcio, 2009).

Methodology and research methods. The present research focuses on the field of modern innovative management tools, namely the Total Quality Management (TQM) tool. We examined the way the individual factors are related to the application of this tool in small and medium-sized enterprises. The relevant factors were defined using established hypotheses which were subsequently statistically tested to prove significant relations between these factors. The dependencies stated in the hypotheses were verified by using statistical tests.

The chief research method used in the study was a questionnaire-based tool. The questionnaire was distributed as an online google form, which is one of the most widely used applications. The questionnaire was divided into three parts depending on whether it contained research questions and identification questions. The first part of the questionnaire consisted of questions identifying the size of the enterprise, its ownership and its geographic reach. The second part concentrated on the use of management tools and the third part was dedicated to the TQM management tool. The questionnaire contained open-ended questions or multiple-choice questions and Likert scale questions. The five-point scale Likert scale form 

Medium-Sized Enterprises

was used to allow the respondents to express how much they agree or disagree with a particular statement.

Since the present research focused on small and medium enterprises, the questionnaire was distributed merely to these entities. The selection of small and medium-sized enterprises was made by the probability theory, which makes it possible to find, according to the probability of one random event, other random events that are in a certain manner related to the first one. Based on the probability theory, it was possible to generalize the results to the entire sample, which was further analyzed, i.e. a census was conducted. The selection of small and medium-sized enterprises was made through random sampling, in which each member of the subset had an equal probability of being chosen. The following hypotheses were formulated in the present research:

$\mathrm{H} 1$ : We assume that there is a statistically significant relationship between the lack of financial resources and the use of Total Quality Management.

$\mathrm{H} 2$ : We assume that there is a statistically significant relationship between the lack of personnel and the use of Total Quality Management.

$\mathrm{H} 3$ : We assume that there is a statistically significant relationship between the incongruity of managers' ideas and the use of the Total Quality Management tool.

The statistical tests indicated in Table 1 were used to verify hypotheses 1.

Table 1. Equations applied in hypothesis verification

\begin{tabular}{|c|c|c|}
\hline Indicator & Formula & Explanatory note \\
\hline $\begin{array}{c}\text { Pearson's } \\
\begin{array}{c}\text { Chi-square Test } \\
\text { of Independence }\end{array}\end{array}$ & $x^{2}=\sum \frac{\left(\mathrm{f}_{\mathrm{e}}-\mathrm{f}_{\mathrm{t}}\right)^{2}}{\mathrm{f}_{\mathrm{t}}}$ & $\begin{array}{r}\chi^{2}-\text { the Chi-square value subsequently compared to a table value based } \\
\text { on the selected error probability, }\end{array}$ \\
$\begin{array}{r}\text { fe-the empirical frequency of observed variables, } \\
\mathrm{ft}-\text { the theoretical frequency of observed variables. }\end{array}$
\end{tabular}

Source: modified according to Marcheova, Tirpakova and Stehlikova, 2011.

Results. The present research focused on using TQM, an innovative management tool, in small and medium-sized enterprises in Slovakia. In the selection of the businesses, their taxonomy based on the industrial classification of economic activities (OKEC) and SK NACE were used. For the present research, the Entrepreneur Index database containing a list of small and medium-sized enterprises in Slovakia was used as a reference. From this database, 613 small and medium-sized enterprises were approached. 63 responses from all respondents were achieved, i.e. the response rate was $10.27 \%$. The graph in Figure 2 provides the basic data concerning the number of respondents involved in the present survey.
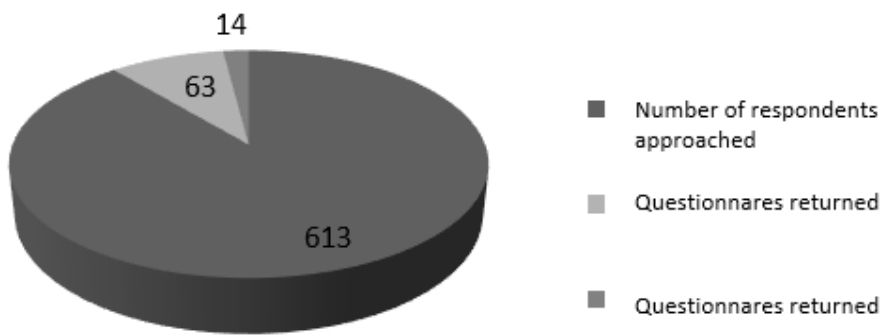

Figure 2. Respondents' identification data

Source: the authors' input based on the questionnaire research.

Verification of the hypotheses. In the present research, innovative management tools were examined with special focus on Total Quality Management. The following hypothesis was proposed: 
$\mathrm{H} 1$ : We assume that there is a statistically significant relationship between the lack of financial resources and the use of the Total Quality Management tool. The table below (Table 2) shows the test results.

Table 2. The results of testing $\mathrm{H} 1$

\begin{tabular}{|c|c|}
\hline \multicolumn{2}{|c|}{ Pearson's Chi-square Test of Independence } \\
\hline Calculated value & $\mathrm{p}=0.04633$ \\
\hline Error profitability & $\alpha=5 \%(0.05)$ \\
\hline Degree of freedom & $\mathrm{DF}=1.00$ \\
\hline Critical value & $\mathrm{x}^{2}=0,01$ \\
\hline
\end{tabular}

Source: the authors' input based on the questionnaire research.

In testing the hypothesis, the value of $p<0.05$ was achieved. The above-given results show that there is a statistically significant relationship between the lack of financial resources and the use of the Total Quality Management tool. The above calculation is graphically illustrated in Figure 3 indicating the dependence between the lack of financial resources and the use of the Total Quality Management tool thus confirming the existence of the relationship between the factors in question.

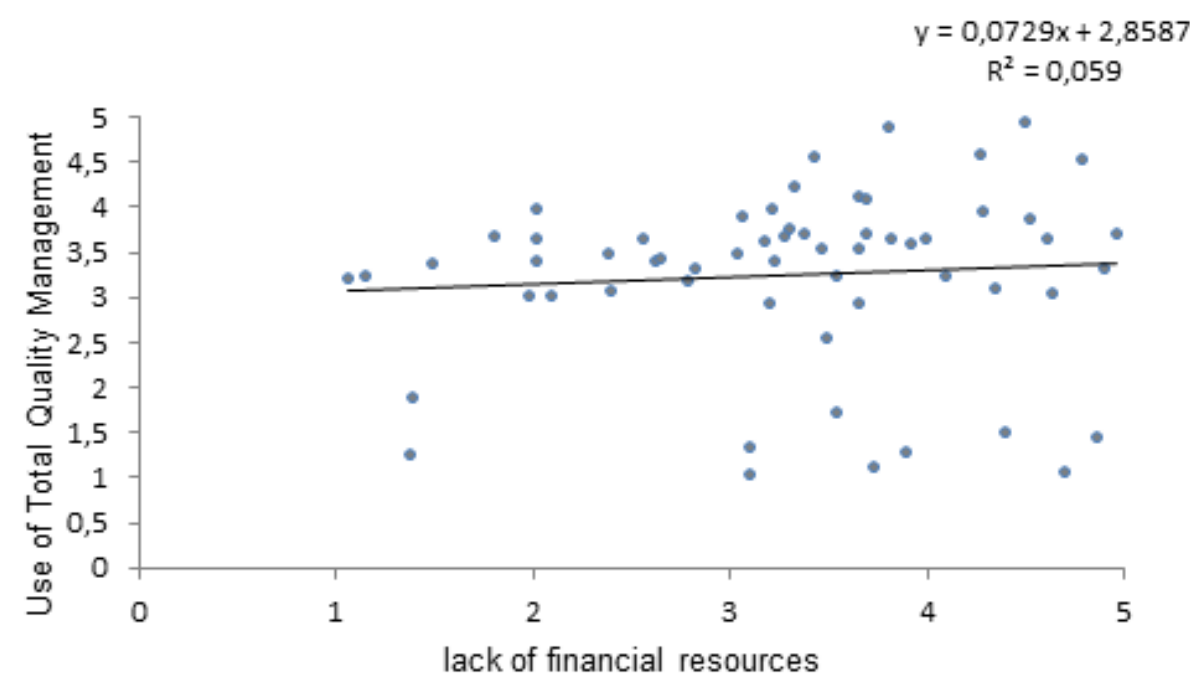

Figure 3. Dependencies between the lack of financial resources and the use of TQM

Source: the authors' input based on the questionnaire research.

As a result, 0 testing the hypothesis the value of $p<0.05$ was reached indicating that there is a statistically significant relationship between the lack of financial resources and the use of the Total Quality Management tool. Therefore, it is possible to conclude that the requirements for accepting the hypothesis were met.

The second hypothesis focusing on the factors preventing the use of the Total Quality Management tool was also statistically tested. It was formulated as follows:

$\mathrm{H} 2$ : We assume that there is a statistically significant relationship between the lack of human resources and the use of the Total Quality Management tool.

Table 3 gives the results of the performed test. 
P. Gallo, B. Balogova, L. Tomcikova \& J. Nemec. The Impact of the Innovative Total Quality Management Tool in Small and Medium-Sized Enterprises

Table 3. Results of testing $\mathrm{H} 2$

\begin{tabular}{|c|c|}
\hline \multicolumn{2}{|c|}{ Pearson's Chi-square Test of Independence } \\
\hline Calculated value & $\mathrm{p}=0.04892$ \\
\hline Error profitability & $\alpha=5 \%(0.05)$ \\
\hline Degree of freedom & $\mathrm{DF}=1.00$ \\
\hline Critical value & $\mathrm{x}^{2}=0,01$ \\
\hline
\end{tabular}

Source: the authors' input based on the questionnaire research.

Similarly, as a result of testing the hypothesis the value of $p<0.05$ was reached. As in the previous case, the hypothesis testing shows that there is a statistically significant relationship between the lack of personnel and the use of the Total Quality Management tool. The above calculation is graphically illustrated in Figure 4 shows the dependence between the lack of human resources and the use of the Total Quality Management tool thus confirming the dependence between the factors in question.

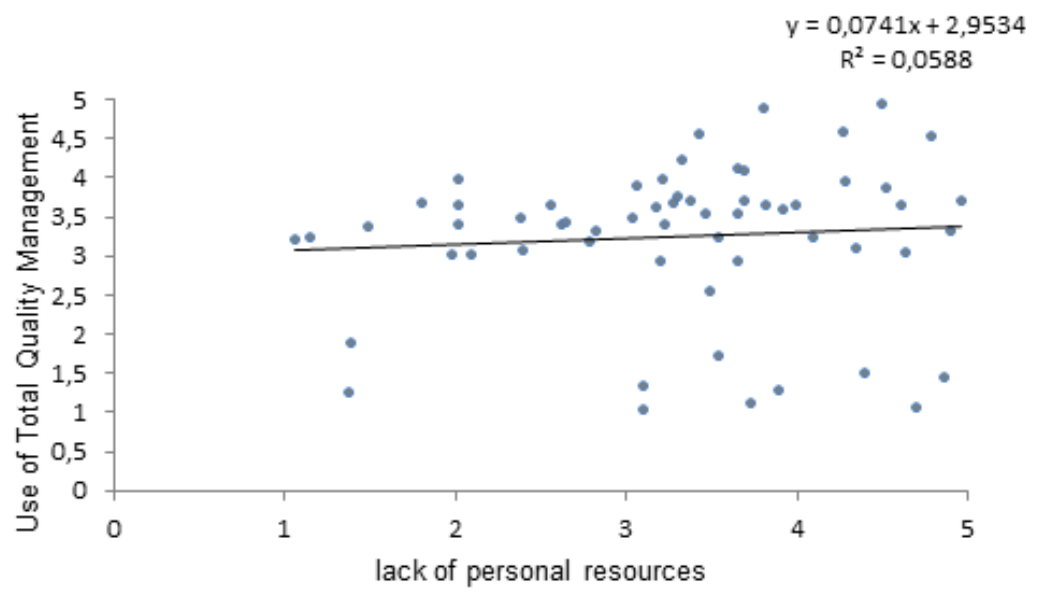

Figure 4. Dependencies between the lack of human resources and the use of TQM tool

Source: the authors' input based on the questionnaire research.

In this case, too, the value of $p<0.05$ was achieved, i.e. there is a statistically significant relationship between the lack of personnel and the use of the Total Quality Management tool. Therefore, the requirements for accepting the hypothesis were met in this case as well.

The third hypothesis focused on the discrepancy between the managers' ideas and the use of Total Quality Management tool. The hypothesis was formulated as follows:

$\mathrm{H} 3$ : We assume that there is a statistically significant relationship between the incongruity of managers' ideas and the use of Total Quality Management tool.

Table 4 presents the performed test results.

Table 4. The results of testing hypothesis

\begin{tabular}{|c|c|}
\hline \multicolumn{2}{|c|}{ Pearson's Chi-square Test of Independence } \\
\hline Calculated value & $\mathrm{p}=0.07884$ \\
\hline Error profitability & $\alpha=5 \%(0.05)$ \\
\hline Degree of freedom & $\mathrm{DF}=1.00$ \\
\hline Critical value & $\mathrm{x}^{2}=0,01$ \\
\hline
\end{tabular}

Source: the authors' input based on the questionnaire research. 
The hypothesis concerning the incongruity of the managers' ideas and the use of the Total Quality Management tool was not confirmed because in the statistical verification based on the Chi-square test the $p>0.05$ was obtained. Therefore, it is possible to conclude that there is no statistically significant relationship between the incongruity of managers' ideas and the use of the Total Quality Management tool. The calculation is graphically illustrated in Figure 5.

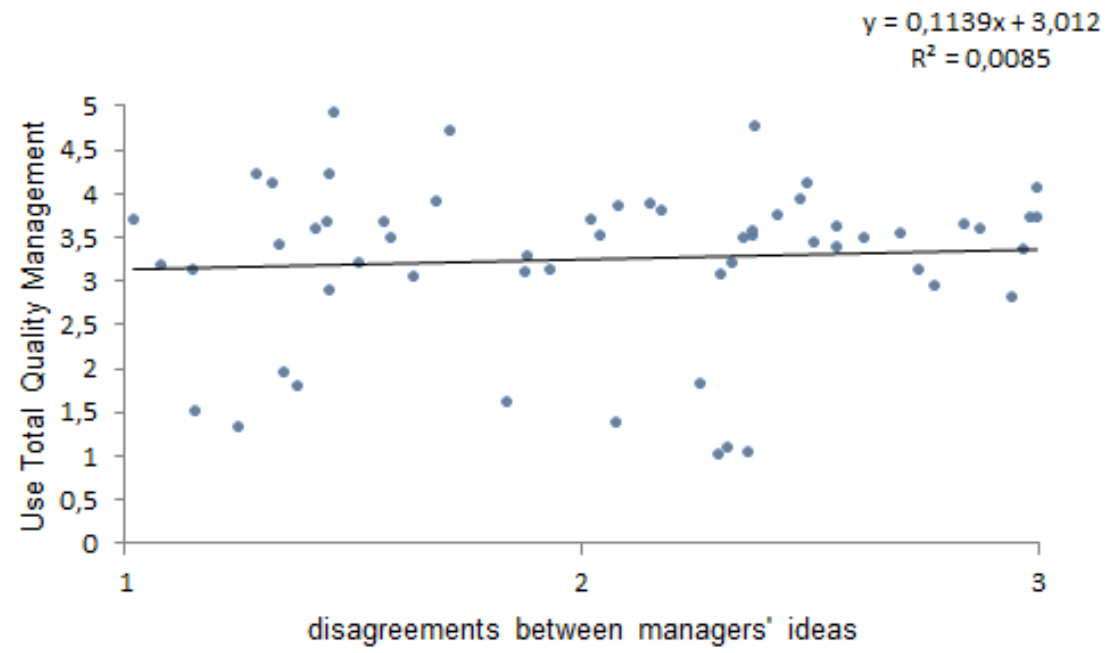

Figure 5. Dependencies between the incongruity of managers' ideas and the use of TQM tool Source: the authors' input based on the questionnaire research.

Statistical verification of the hypothesis resulted in $p=0.05$. Based on this calculation, it is possible to conclude that there is no statistically significant relationship between the incongruity of managers' ideas and the use of the Total Quality Management tool. Therefore, this hypothesis was refuted.

Conclusions. The pre-research focused on the innovative management tools with a more detailed focus on the use of Total Quality Management tool. The number of respondents in the conducted research comprised approximately $10 \%$ of the total sample. For questionnaire-based research, such a research sample is considered relevant. Based on the present research, the factors preventing more extensive use of the management tool in question were defined, such as the lack of financial resources and personnel and the incongruity of managers' ideas. The impact of the first two factors was proved by statistical tests. The third factor, namely the incongruity of the managers' ideas, was not statistically confirmed thus suggesting that this factor does not have any significant impact on the use of TQM tool. Certain limitations in the present research were detected. These include the size of the research sample is merely $10 \%$ of the total number of approached respondents. A greater response rate would have provided a more comprehensive and realistic view of the explored issue. As a further limitation, the focus of research on small and medium-sized enterprises may be pointed at. In other segments, the situation with the use of management tools might look different. Nevertheless, the said limitations motivate us in conducting further research on the issue of application of innovative management tools.

Author contribution statement. Conceptualization, P. G. data curation, P. G. and B. B; formal analysis, P. G. and B. B.; funding acquisition, J.N.; investigation, P. G., B. B. and L. T.; methodology, P. G. and L. T.; project administration, P. G., B. B., L. T. and J. N.; resources, B. B.; software, P. G.; supervision, P. G. and B. B.; validation, P. G. and B. B.; visualization, J. N. and B. B.; writing - original draft, P. G., B. B., L. T. and J. N. 
P. Gallo, B. Balogova, L. Tomcikova \& J. Nemec. The Impact of the Innovative Total Quality Management Tool in Small and Medium-Sized Enterprises

Funding. This paper is an outcome of the VEGA scientific project No. 1/0134/17 Importance of value orientation - expectations and prospects of the young generation concerning their employability.

\section{References}

Al Taweel, I. R. (2019). The impact of the organizational cultures on the job performance in the GCC companies. Marketing and Management of Innovations, 3, 265-271. http://doi.org/10.21272/mmi.2019.3-20

Abdul, A.R.Z., Sumantoro, I.B. \& Maria, D. (2019). Total quality management of micro, small and medium enterprises (MSMEs), and the impact to organizational culture and performance: Emerging country case. Polish Journal of Management Studies 19 (1). pp. 32-45. doi: 10.17512/pjms.2019.19.1.03

Beard-Gunter, A., Ellis, D.G. \& Found, P.A. (2019). TQM, games design and the implications of integration in Industry 4.0 systems (Review). International Journal of Quality and Service Sciences 11 (2). pp. 235-247

Beer, M. (2003). Why Total Quality Management Programs Do Not Persist: The Role of Management Quality and Implications for Leading a TQM Transformation. Decision Sciences, 34 (4), pp. 623-642. doi: 10.1111/j.1540-5414.2003.02640.x

Bilan, Y., Lyeonov, S., Lyulyov, O. \& Pimonenko, T. (2019). Brand management and macroeconomic stability of the country. Polish Journal of Management Studies 19 (2). pp. 61-74. doi: 10.17512/pjms.2019.19.2.05

Bilan, Y., Vasilyeva, T., Lyulyov, O. \& Pimonenko, T. (2019). EU vector of Ukraine development: Linking between macroeconomic stability and social progress. International Journal of Business and Society 20 (2). pp. 433-450

Bolboli, S.A., Reiche, M. (2014). Culture-based design and implementation of business excellence. TQM Journal, 26 (4), art. no. 17112002, pp. 329-347. doi: 10.1108/TQM-01-2014-0015

Butko, M., Popelo, O., \& Pishenin, I. (2019). Innovations in Human Resources Management in Eurointegration Conditions: Case for Ukrainian Agro-Industrial Complex. Marketing and Management of Innovations, 2, 74-82. http://doi.org/10.21272/mmi.2019.2-07

Calvo-Mora, A., Picon, A., Ruiz, C., Cauzo, L. (2014). The relationships between soft-hard TQM factors and key business results. International Journal of Operations and Production Management, 34 (1), pp. 115-143. doi: 10.1108/IJOPM-09-2012-0355

Colurcio, M. (2009). TQM: A knowledge enabler?. TQM Journal, 21 (3), pp. 236-248. doi: 10.1108/17542730910953013

Dahlgaard-Park, S.M. (2012). Core values - the entrance to human satisfaction and commitment. Total Quality Management and Business Excellence, 23 (2), pp. 125-140. doi: 10.1080/14783363.2012.655067

Diaper, D., Sanger, C. (2006). Tasks for and tasks in human-computer interaction. Interacting with Computers, 18 (1 SPEC. ISS.), pp. 117-138. doi: 10.1016/j.intcom.2005.06.004

Feigenbaum, A. V. \& Feigenbaum, Donald S. (2009). The power of management innovation : 24 keys for sustaining and accelerating business growth and profitability, McGraw-Hill mighty manager handbooks., McGraw-Hill

Ghani Al-Saffar, N.A. \& Obeidat, A.M. (2020). The effect of total quality management practices on employee performance: The moderating role of knowledge sharing. Management Science Letters 10 (1). pp. 77-90. doi: 10.5267/j.msl.2019.8.014

Hakobyan, N., Khachatryan, A., Vardanyan, N., Chortok, Y., \& Starchenko, L. (2019). The Implementation of Corporate Social and Environmental Responsibility Practices into Competitive Strategy of the Company. Marketing and Management of Innovations, 2, 42-51. http://doi.org/10.21272/mmi.2019.2-04

Chountalas, P.T. \& Lagodimos, A.G. (2019). Paradigms in business process management specifications: a critical overview.

Business Process Management Journal 25 (5). pp. 1040-1069. doi: 10.1108/BPMJ-01-2018-0023

Kisel'akova, D., Sofrankova, B., Gombar, M., Cabinova, V. \& Onuferova, E. (2019). Competitiveness and its impact on sustainability, business environment, and human development of EU (28) countries in terms of global multi-criteria indices

Sustainability (Switzerland) 11 (12)., pp. 3365. doi: 10.3390/su10023365

Kosikova, M., Vasanicova, P. \& Litavcova, E. (2019). Analysis of aspects of the tourism development in Slovakia in the Context of the European Space. Montenegrin Journal of Economics. 15 (2). pp. 127-137. DOI: 10.14254/1800-5845/2019.15-2.10

Laguna, M. (2013). Self-efficacy, self-esteem, and entrepreneurship among the unemployed. Journal of Applied Social Psychology, 43 (2), pp. 253-262. doi: 10.1111/j.1559-1816.2012.00994.x

Lin, C.-N., Wu, J.-H. \& Roan, J. (2019). The growth stage model of quality information systems-an example of manmade fibre industry. Total Quality Management and Business Excellence. 30 (9-10). pp. 1026-1041. doi: 10.1080/14783363.2017.1347036

Marcheova, D., Tirpakova, A. \& Stehlikova, B. (2011). Zaklady statistiky pre pedagogov [The Essentials of Statistics for teachers]. UKF Nitra.

Nizamidou, C., Vouzas, F. \& Gotzamani, K.E. (2019). Exploring the interrelationship between quality, safety and HR within crisis management framework. TQM Journal 31 (4). pp. 541-562. doi: 10.1108/TQM-08-2018-0106

Mitreva, E., Sazdova, J. \& Gjorshevski, H. (2019). Quality management system applications in the hotel industry in macedonia Quality - Access to Success 20 (170). pp. 68-72.

Onuferova, E., Cabinova, V. (2018). Enterprise Performance Analysis of the Selected Service Sector by Applying Modern Methods with an Emphasis on the Creation and Application of the Modified Creditworthy Model (MCWM). Journal of tourism and services. 9 (17). pp. 97-122. doi:10.29036/jots.v9i17.74.

Oluwafemi, I. \& Laseinde, T. (2019). Useful Total Quality Management Critical Success Fundamentals in Higher Education 
P. Gallo, B. Balogova, L. Tomcikova \& J. Nemec. The Impact of the Innovative Total Quality Management Tool in Small and Medium-Sized Enterprises

Institution (Conference Paper). Advances in Intelligent Systems and Computing. 1026. pp. 1066-10742.

Pietruszka-Ortyl, A. (2019). The Impact of Organizational Culture for Company's Innovation Strategy. Marketing and Management of Innovations, 3, 178-192. http://doi.org/10.21272/mmi.2019.3-14.

Prokopenko, O., Holmberg R., \& Omelyanenko, V. (2018). Information and communication technologies support for the participation of universities ininnovation networks (comparative study). Innovative Marketing, 14(3), 17-29 doi:10.21511/im.14(3).2018.03.

Ruiz, E., De Pablo, J.D.S., Munoz, R.M. \& Pena, I. (2019). Do high performance work systems enhance business performance? Examining the mediating influence of total quality management. Zbornik Radova Ekonomskog Fakultet au Rijeci 37 (1). pp. 235-258. doi: 10.18045/zbefri.2019.1.235.

Sahoo, S. (2019). Assessment of TPM and TQM practices on business performance: a multi-sector analysis. Journal of Quality in Maintenance Engineering 25 (3). pp. 412-434. doi: 10.1108/JQME-06-2018-0048

Tenji, T. \& Foley, A. (2019). Testing the readiness of an organisational culture profile to a TQM implementation. TQM Journal. 31, (3). pp. 400-416. doi: 10.1108/TQM-01-2018-0002.

Петер Галло, Ph.D., Пряшівський університет у Пряшеві (Словаччина);

Бєата Балагова, професор, Пряшівський університет у Пряшеві (Словаччина);

Люба Томчікова, Ph.D., Пряшівський університет у Пряшеві (Словаччина);

Джозеф Немеч, Ph.D., Пряшівський університет у Пряшеві (Словаччина).

Вплив інноваційних інструментів оцінювання якості управління на функціонування малого та середнього бізнесу

у статті досліджено основні перспективи та особливості використання інструментів оцінювання якості системи управління - Total Quality Management (TQM) у малому та середньму бізнесі, на прикладі Словаччини. Визначено основні фоктори-дестимулятори використання інструментів TQM. При иьому вченими TQM розглядається як інноваційний інструмент системи менеджменту підприємств малого та середнього бізнесу. Систематизація результатів аналізу праць провідних учених у даній сфрері засвідчили, що TQM є ключовим елементом ефективної системи менеджменту підприємств малого та середнього бізнесу. Основними гіпотезами дослідження є перевірка наявності статистично значущих зв'язків між нестачею трудових та фрінансових ресурсів, з одного боку, та ефективністью використання інноваційних інструментів TQM, з іншого. Перевірку висунутих гіпотез здійснено з використанням економіко-математичних та статистичних методів, а саме: критерій Хі-квадрат ступеня свободи. Емпіричні результати дослідження підвтердили наявність статистично значущих зв'язків між обраними змінними, значення р було нижчим за 0,05. Враховуючі отримані результати авторами визначено, що брак фрінансових ресурсів та недостатня кількість кваліфрікованої робочої сили є одним з основних бар'єрів ефективної імплементації інструментів TQM. Окрім цього, у статті визначено, що другим дестимуляторм є не розуміння менеджментом малих та середніх підприємств доцільності імплементації інструментів TQM та не узгодженість стратегій майбутнього розвитку. При цьому розрахункові дані спростували дану гіпотезу, оскільки р>0,05. Авторами системматизовано основні переваги використання TQM як інноваційного інструменти управління. У статті зазначено, що імплементація інструментів TQM дозволить оцінити ефективність управління, узгодити фрінансові та нефрінансові цілі розвитку і, як наслідок, підвищити конкурентоспроможність малих та середні підприємствм, що забезпечить зростання обсягів надходження фінансових ресурсів від зацікавлених сторін у їх розвиток

Ключові слова: загальне управління якістю, інноваційні інструменти управління, малі та середні підприємства, результативність

Manuscript received: 06.06.2019.

(C) The author(s) 2019. This article is published with open access at Sumy State University. 